\title{
SYNTHESIS AND REACTIVITY OF PYRROLIDE-DIIMINE COMPLEXES OF CHROMIUM
}

\author{
Brian A. SAlisbury ${ }^{1}$, John F. YOUNG ${ }^{2}$, Glenn P. A. YAP ${ }^{3}$ and \\ Klaus H. THEOPOLD ${ }^{4 *}$ \\ Department of Chemistry and Biochemistry, Center for Catalytic Science and Technology, \\ University of Delaware, Newark, Delaware 19716, U.S.A.; \\ e-mail: ${ }^{1}$ brian.salisbury@lyondell.com, ${ }^{2}$ youngjo@udel.edu, ${ }^{3}$ gpyap@udel.edu, \\ ${ }^{4}$ theopold@udel.edu
}

Received February 12, 2007

Accepted April 1, 2007

Dedicated to Dr Karel Mach on the occasion of his 70th birthday, in appreciation of his substantial contribution to the organometallic chemistry of early transition metals and for his gracious hospitality extended to visitors to "the golden city" of Prague.

Lithium 2,5-bis $\left\{\right.$ (2,6-diisopropylphenyl)imino]methyl \}pyrrol-1-ide (LiL) reacts with $\left[\mathrm{CrCl}_{3}\left(\right.\right.$ thf) $\left.{ }_{3}\right]$ to yield the octahedral complex $\left[\left(\eta^{2}-\mathrm{L}\right) \mathrm{CrCl}_{2}(\text { thf })_{2}\right](\mathbf{1})$, in which only two of the three potential nitrogen donors are coordinated to chromium. In the presence of various alkyl aluminum cocatalysts, $\mathbf{1}$ catalyzes the polymerization of ethylene. Attempts to prepare alkyl derivatives of $\mathbf{1}$ were thwarted by an apparent disproportionation, yielding divalent $\left[\left(\eta^{2}-L\right)\left(\eta^{1}-L\right) C r(\right.$ thf $\left.)\right](2)$. The molecular structures of $\mathbf{1}$ and $\mathbf{2}$ have been determined by $X$-ray diffraction. The structure of $\mathbf{2}$ is unusual in that it features weak, but equivalent interactions of both imine groups of the $\eta^{1}$-pyrrolide ligands with the chromium, giving rise to an approximately octahedral coordination geometry with two extremely long $\mathrm{Cr}-\mathrm{N}$ distances.

Keywords: Chromium complexes; Pyrrolide-diimine ligands; Polymerization; Ethylene; Homogeneous catalysis; X-ray diffraction.

The design of new ligand frameworks for transition metal catalyzed olefin polymerization is a topic of current interest in organometallic chemistry. The investigation of new ligands has been driven by the desire to produce well-defined catalysts that have high polymerization activity and generate polymers with new and useful properties. Recent innovations in the area of ligand design include the bis(imino)pyridines ${ }^{1}, \alpha$-diimines ${ }^{2}$ and phenolate imines $^{3}$. These ligands have seen extensive use mainly for late transition metal (i.e., Fe, Co, Ni, Pd) catalyzed olefin polymerization.

Other ligand designs that are of current interest are the pyrrolide-imine 4 and pyrrolide-diimine ${ }^{5}$ ligands. Pyrrolide-imines and in particular pyrrolide- 
diimines are sterically demanding monoanionic ligands that have the potential to bind to a metal atom in a bi- or tridentate fashion. These ligands can stabilize the higher oxidation states of early transition metal catalysts by providing hard nitrogen donor atoms. They can also provide steric protection of the metal site by substituted aryl groups on the imine nitrogens, thus stabilizing coordinatively unsaturated metal complexes. These properties make these ligands suitable candidates for early transition-metal olefin polymerization catalysts.

In a program directed at discovery of new chromium(III) olefin polymerization catalysts, we have investigated the synthesis and polymerization activity of chromium pyrrolide-diimine complexes.

\section{EXPERIMENTAL}

\section{General}

All manipulations of compounds were performed with standard Schlenk, high vacuum line, or inert atmosphere glove box techniques, using nitrogen as the inert gas. Pentane, diethyl ether and toluene were distilled from purple sodium/benzophenone ketyl. Tetrahydrofuran (THF) was distilled from purple potassium/benzophenone ketyl. $\mathrm{CD}_{2} \mathrm{Cl}_{2}$ was dried with calcium hydride and stored under vacuum over $4 \AA$ molecular sieves. The following starting materials were made by the literature methods: Lithium 2,5-bis $\{(2,6$-diisopropylphenyl)imino]methyl \}pyrrol-1-ide ${ }^{6}$ and $\left[\mathrm{CrCl}_{3}\left(\mathrm{thf}_{3}\right]^{7}\right.$. [(Trimethylsilyl)methyl]lithium (TMSM Li) was purchased from Aldrich Chemical Company as a $1.0 \mathrm{M}$ solution; it was crystallized from pentane and used as a solid. Other standard reagents were purchased from Aldrich Chemical Co., Acros Organics, or Strem Chemical Co. and used as received.

NMR spectra $(\delta, \mathrm{ppm})$ were recorded on a Bruker AMX 360 spectrometer $\left(360 \mathrm{MHz}\right.$ for $\left.{ }^{1} \mathrm{H}\right)$ and were referenced to the residual ${ }^{1} \mathrm{H}$ or trace ${ }^{13} \mathrm{C}$ resonances of the solvent $\left(\mathrm{CDHCl}_{2}:{ }^{1} \mathrm{H}\right.$ NMR: $5.32 \mathrm{ppm},{ }^{13} \mathrm{C}$ NMR: $\left.54.00 \mathrm{ppm}\right)$. FTIR spectra $\left(v, \mathrm{~cm}^{-1}\right)$ were recorded on a Mattson Alpha Centauri spectrometer with a resolution of $4 \mathrm{~cm}^{-1}$. UV/VIS spectra $\left(\lambda, \mathrm{nm} ; \varepsilon, \mathrm{M}^{-1} \mathrm{~cm}^{-1}\right)$ were recorded using a Hewlett-Packard model 8453 spectrophotometer. Elemental analyses were performed by Prevalere Life Sciences Inc., Whitesboro (NY) 13492. Characterization of polyethylene samples was conducted by Chevron Philips Chemical Company, Bartlesville (OK).

Room temperature magnetic susceptibilities were determined using a Johnson Matthey Magnetic Susceptibility Balance, which utilizes a modification of the Gouy method. Molar magnetic susceptibilities were corrected for diamagnetism using Pascal constants ${ }^{8}$, and the effective magnetic moments were calculated from the expression

$$
\mu_{\text {eff }}=2.828 \sqrt{\chi_{m}^{\top}}
$$

where $\mathrm{T}$ is the absolute temperature in $\mathrm{K}$ and $\chi_{\mathrm{m}}$ is the molar magnetic susceptibility corrected for diamagnetism. 
Synthesis of (2,5-Bis\{(2,6-diisopropylphenyl)imino]methyl \}pyrrol-1-ido)dichlorobis(tetrahydrofuran)chromium(III) (1)

$\left[\mathrm{CrCl}_{3} \text { (thf) }\right)_{3}$ (1.26 g, $\left.3.36 \mathrm{mmol}\right)$ was suspended in $50 \mathrm{ml}$ of THF. Lithium 2,5-bis$\{(2,6$-diisopropylphenyl)imino]methyl \}pyrrol-1-ide $(1.52 \mathrm{~g}, 3.36 \mathrm{mmol})$ was dissolved in $25 \mathrm{ml}$ of THF. A THF solution of the lithium salt was slowly added to the purple chromium chloride slurry via pipette at room temperature. The reaction mixture was allowed to stir at room temperature for $12 \mathrm{~h}$. The THF was evaporated and the residue extracted with diethyl ether. Concentration, layering with pentane, and cooling of the diethyl ether solution to $-30{ }^{\circ} \mathrm{C}$ yielded $1.40 \mathrm{~g}(1.98 \mathrm{mmol})$ of compound $\mathbf{1}$ as dark brown crystals in $59 \%$ yield. ${ }^{1} \mathrm{H} N M R\left(\mathrm{CD}_{2} \mathrm{Cl}_{2}\right)$ : $17.3(\mathrm{v} \mathrm{br}, 1 \mathrm{H}) ; 10.7(\mathrm{br}, 2 \mathrm{H}) ; 8.8(\mathrm{br}, 1 \mathrm{H}) ; 8.1(\mathrm{sh}, 1 \mathrm{H}) ; 7.9(\mathrm{br}, 1 \mathrm{H})$; $7.2(\mathrm{br}, 1 \mathrm{H}) ; 6.5(\mathrm{br}, 1 \mathrm{H}) ; 3.7(\mathrm{sh}, 8 \mathrm{H}) ; 2.4(\mathrm{sh}, 4 \mathrm{H}) ; 1.8(\mathrm{sh}, 8 \mathrm{H}) ; 1.2(\mathrm{v} \mathrm{br}, 24 \mathrm{H})$. IR (KBr): 2596 (s), $2855(\mathrm{w}), 2486(\mathrm{w}), 1593(\mathrm{~m}), 1575$ (s), $1483(\mathrm{~m}), 1439(\mathrm{w}), 1310(\mathrm{~m}), 1163$ (m), $1108(w), 1047(\mathrm{~m}), 1012(\mathrm{w}), 856(\mathrm{~m})$. UV/VIS (Et $\left.{ }_{2} \mathrm{O}\right): 543(\varepsilon=266), 580(\varepsilon=262), 625$ $(\varepsilon=219)$. M.p. $160{ }^{\circ} \mathrm{C}(\mathrm{dec}) . \mu_{\text {eff }}=3.9(1) \mu_{\mathrm{B}}(298 \mathrm{~K})$. For $\mathrm{C}_{38} \mathrm{H}_{54} \mathrm{Cl}_{2} \mathrm{CrN}_{3} \mathrm{O}_{2}$ (707.8) calculated: $64.49 \%$ C, $7.69 \% \mathrm{H}, 5.94 \% \mathrm{~N}$; found: $63.82 \% \mathrm{C}, 7.42 \% \mathrm{H}, 5.80 \% \mathrm{~N}$.

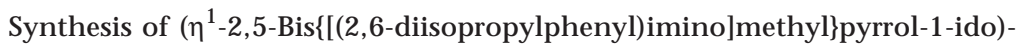

( $\eta^{2}-2,5$-bis $\{(2,6$-diisopropylphenyl)imino]methyl \}pyrrol-1-ido)-

(tetrahydrofuran)chromium(II) (2)

$\mathrm{CrCl}_{2}(0.046 \mathrm{~g} 0.37 \mathrm{mmol})$ was suspended in $25 \mathrm{ml}$ of THF. A THF solution of lithium 2,5-bis $\{$ (2,6-diisopropylphenyl)imino]methyl \}pyrrol-1-ide $(0.338 \mathrm{~g}, 0.76 \mathrm{mmol})$ was slowly added via pipette over $3 \mathrm{~min}$. The yellow slurry slowly turned light brown and was allowed to stir for $12 \mathrm{~h}$. After stirring overnight, the solution had turned dark brown and the THF was evaporated. Extraction with diethyl ether, followed by filtration, afforded an orangebrown solution. Concentration, layering with pentane, and crystallization at $-30{ }^{\circ} \mathrm{C}$ gave $0.285 \mathrm{~g}(0.28 \mathrm{mmol})$ of complex 2 as orange crystals in $76 \%$ yield. ${ }^{1} \mathrm{H} \mathrm{NMR}\left(\mathrm{CD}_{2} \mathrm{Cl}_{2}\right): 38.1$ (v br); 13.4 (br); 11.4 (br); 9.7 (br); 6.2 (sh); 1.3 (br); 0.9 (sh); -1.2 (sh); -32.0 (br); -42.9 (br); $-50.9(\mathrm{v} \mathrm{br})^{9}$. IR (KBr): $3060(\mathrm{w}), 2960(\mathrm{~s}), 2927(\mathrm{~m}), 2885(\mathrm{~m}), 1567(\mathrm{~s}), 1481(\mathrm{~m}), 1435(\mathrm{~m})$, $1398(w), 1381(w), 1360(\mathrm{~m}), 1319(\mathrm{~s}), 1276(\mathrm{~m}), 1164(\mathrm{~s}), 1108(\mathrm{~m}), 1058(\mathrm{~m}), 1042(\mathrm{~m})$, $932(\mathrm{w}), 865(\mathrm{w}), 771(\mathrm{~m}), 737(\mathrm{~m})$. UV/VIS (pentane): $511(\varepsilon=493), 548(\varepsilon=380), 594(\varepsilon=$ 155). M.p. $180{ }^{\circ} \mathrm{C}$ (dec). $\mu_{\text {eff }}=4.6(1) \mu_{\mathrm{B}}(294 \mathrm{~K})$. For $\mathrm{C}_{64} \mathrm{H}_{84} \mathrm{CrN}_{6} \mathrm{O}$ (1005.4) calculated: $76.46 \%$ C, $8.42 \% \mathrm{H}, 8.36 \% \mathrm{~N}$; found: $76.77 \% \mathrm{C}, 9.20 \% \mathrm{H}, 8.29 \% \mathrm{~N}$.

Attempted Alkylation of (2,5-Bis\{(2,6-diisopropylphenyl)imino]methyl \}pyrrol-1-ido)dichlorobis(tetrahydrofuran)chromium(III) (1) with [(Trimethylsilyl)methyl]lithium

Complex 1 ( $0.500 \mathrm{~g}, 0.71 \mathrm{mmol})$ was dissolved in $50 \mathrm{ml}$ of THF and stirred for $5 \mathrm{~min}$ to ensure complete dissolution. TMSMLi $(66.5 \mathrm{mg}, 0.71 \mathrm{mmol}$ ) was added as a solid to the brown solution of $\mathbf{1}$. The color changed slightly to a lighter brown. The reaction was allowed to stir for $3 \mathrm{~h}$ after which the THF was evacuated. The residue was extracted into pentane and filtered to remove lithium chloride. The light brown pentane solution was concentrated and cooled to $-30{ }^{\circ} \mathrm{C}$, whereupon $0.085 \mathrm{~g}(84.8 \mu \mathrm{mol})$ of light brown-orange crystals were isolated in $12 \%$ yield. The ${ }^{1} \mathrm{H}$ NMR spectrum of these crystals identified the product as compound 2. 
Single-Crystal X-ray Diffraction Studies

Crystal data and structure refinement details are shown in Table I. Crystals were selected and mounted on glass fibers with viscous oil and cooled to the data collection temperature. Diffraction data were collected on a Bruker-AXS APEX CCD diffractometer. All data-sets were treated with SADABS absorption corrections. Unit-cell parameters were determined by sampling three different sections of the Ewald sphere. Despite repeated attempts, 1 consistently yielded small, multiple, weakly diffracting crystals, which yielded virtually identical unit cell parameters with poor precision. The data reported represent the best effort. No symmetry higher than triclinic was observed in the diffraction data and the structural solution in the centrosymmetric space group option, P-1, yielded chemically reasonable and computationally stable results of refinement for $\mathbf{1}$. The systematic absences in the diffraction data were uniquely consistent for the reported space group $\mathrm{P}_{1} / \mathrm{c}$ for $\mathbf{2}$. All nonhydrogen atoms were refined with anisotropic displacement parameters. All hydrogen atoms were treated as idealized contributions. Structure factors are contained in SHELXTL 6.12 program library (G. Sheldrick, 2001; Siemens XRD, Madison (WI)). CCDC 636297 (1) and 636298 (2) contain the supplementary crystallographic data for this paper. These data can be obtained free of charge via www.ccdc.cam.ac.uk/conts/retrieving.html (or from the Cambridge Crystallographic Data Centre, 12, Union Road, Cambridge, CB2 1EZ, UK; fax: +44 1223 336033; or deposit@ccdc.cam.ac.uk).

TABLE I

Crystallographic data for complexes $\mathbf{1}$ and $\mathbf{2}$

Parameter

Empirical formula

Formula weight, $\mathrm{g} \mathrm{mol}^{-1}$

Crystal system

Space group
a, $\AA$
b, $\AA$
c, $\AA$
$\alpha,{ }^{\circ}$
$\beta, \circ$
$\gamma^{\circ}{ }^{\circ}$
$V, \AA^{3}$
Z
$D_{\text {calc }}, \mathrm{g} \mathrm{cm}^{-3}$
$T, K$

Reflections

Indep. reflections

GOF on $\mathrm{F}^{2}$

$R(F), \%$

$R(w F), \%$
1

$\mathrm{C}_{38} \mathrm{H}_{54} \mathrm{Cl}_{2} \mathrm{CrN}_{3} \mathrm{O}_{2}$
707.74
triclinic
P-1

11.164(12)

11.976(13)

15.387(16)

108.56(2)

104.16(2)

93.04(2)

1872(3)

2

1.256

223(2)

10040

6959

1.016

5.98

15.67
2

$\mathrm{C}_{64} \mathrm{H}_{84} \mathrm{CrN}_{6} \mathrm{O}$

1005.37

monoclinic

$\mathrm{P}_{1} / \mathrm{C}$

21.879(6)

13.466(5)

19.612(5)

90

90.41(3)

90

5778(3)

4

1.156

120(2)

40781

10171

1.036

5.25

11.20 
Polymerization Experiments. General Procedure

Complex $1(0.010 \mathrm{~g})$ was added to $25 \mathrm{ml}$ of toluene in a 300-ml Parr reactor. 100 equivalents of the activator (methylaluminoxane ( $\mathrm{MAO}$ ), $\mathrm{Et}_{2} \mathrm{AlCl}$, or $\mathrm{EtAlCl}_{2}$ ) were added via syringe and the reactor was bolted tight in the dry box. The reactor was removed from the dry box and connected to the ethylene tank. The ethylene supply line was purged for 5 min and then tightened. The stirrer was started and the thermocouple connected. The reactor was opened to the ethylene and the pressure was adjusted to $1.38 \mathrm{MPa}$. The reaction temperature was monitored and the reaction was allowed to stir for $1 \mathrm{~h}$. After $1 \mathrm{~h}$, the pressure was slowly relieved and the reactor was dismantled. The catalyst solution was quenched with $20 \mathrm{ml}$ of a 75:25 mixture of methanol/concentrated $\mathrm{HCl}$. The polyethylene was filtered off by vacuum filtration and dried at $65{ }^{\circ} \mathrm{C}$ in vacuo overnight.

\section{RESULTS AND DISCUSSION}

Reaction of 1 equivalent of lithium 2,5-bis\{(2,6-diisopropylphenyl)imino]methyl \}pyrrol-1-ide with 1 equivalent of $\left[\mathrm{CrCl}_{3}\right.$ (thf) $\left.{ }_{3}\right]$ in THF overnight yielded a dark brown solution. Evaporation of the THF, extraction into diethyl ether, followed by crystallization from diethyl ether layered with pentane yielded (2,5-bis\{(2,6-diisopropylphenyl)imino]methyl \}pyrrol-1-ido)dichlorobis(tetrahydrofuran)chromium(III) (1) in 59\% yield as a dark brown powder (Scheme 1).
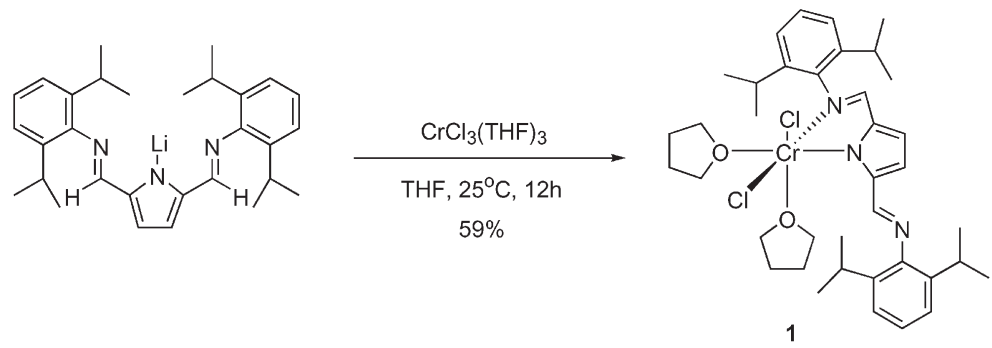

SCHEME 1

Crystals of $\mathbf{1}$ were obtained from THF layered with pentane at $-30{ }^{\circ} \mathrm{C}$ and its molecular structure, as determined by X-ray diffraction, is shown in Fig. 1; selected interatomic distances and angles are listed in Table II. Complex $\mathbf{1}$ adopts an octahedral geometry, with only one of the imino groups bound to the chromium atom. This was not too surprising, as the only reported tridentate pyrrolide-diimine ligand appears in an yttrium complex ${ }^{4 c}$; yttrium has a significantly larger ionic radius than chromium, namely $0.93 \AA$ for six-coordinated $Y(I I I)$, while six-coordinated $\mathrm{Cr}(\mathrm{III})$ has an ionic radius of $0.62 \AA$. This difference is enough to make the chromium bind only one arm of the ligand, while yttrium can bind both. The uncoor- 
dinated imine group has been rotated $180^{\circ}$ away from the chromium atom due to steric repulsions between the large 2,6-diisopropylaniline group and the chloride and THF ligands. The room temperature ${ }^{1} \mathrm{H}$ NMR spectrum of complex 1 shows no evidence for exchange of the imine moieties of the ligand on the chromium atom. The $\mathrm{Cr}(1)-\mathrm{N}(2)$ distance of 2.064(3) $\AA$ as

\section{TABLE II}

Selected interatomic distances and angles in complex $\mathbf{1}$

Distance, $\AA$

$\begin{array}{lll}\mathrm{Cr}(1)-\mathrm{O}(1) & 2.028(3) & \mathrm{N}(2)-\mathrm{Cr}(1)-\mathrm{N}(1) \\ \mathrm{Cr}(1)-\mathrm{O}(2) & 2.050(3) & \mathrm{N}(2)-\mathrm{Cr}(1)-\mathrm{Cl}(1) \\ \mathrm{Cr}(1)-\mathrm{N}(2) & 2.064(3) & \mathrm{N}(1)-\mathrm{Cr}(1)-\mathrm{Cl}(1) \\ \mathrm{Cr}(1)-\mathrm{N}(1) & 2.116(3) & \mathrm{N}(2)-\mathrm{Cr}(1)-\mathrm{Cl}(2) \\ \mathrm{Cr}(1)-\mathrm{Cl}(1) & 2.284(2) & \mathrm{N}(1)-\mathrm{Cr}(1)-\mathrm{Cl}(2) \\ \mathrm{Cr}(1)-\mathrm{Cl}(2) & 2.302(2) & \mathrm{Cl}(1)-\mathrm{Cr}(1)-\mathrm{Cl}(2) \\ \mathrm{N}(1)-\mathrm{C}(13) & 1.280(4) & \mathrm{C}(13)-\mathrm{N}(1)-\mathrm{C}(1) \\ \mathrm{N}(3)-\mathrm{C}(18) & 1.275(4) & \mathrm{C}(13)-\mathrm{N}(1)-\mathrm{Cr}(1) \\ & & \mathrm{C}(1)-\mathrm{N}(1)-\mathrm{Cr}(1)\end{array}$

Angle, ${ }^{\circ}$

$80.93(13)$
$168.66(8)$
$88.25(11)$
$96.78(11)$
$176.64(7)$
$94.17(9)$
$116.6(3)$
$110.8(2)$
$132.6(2)$

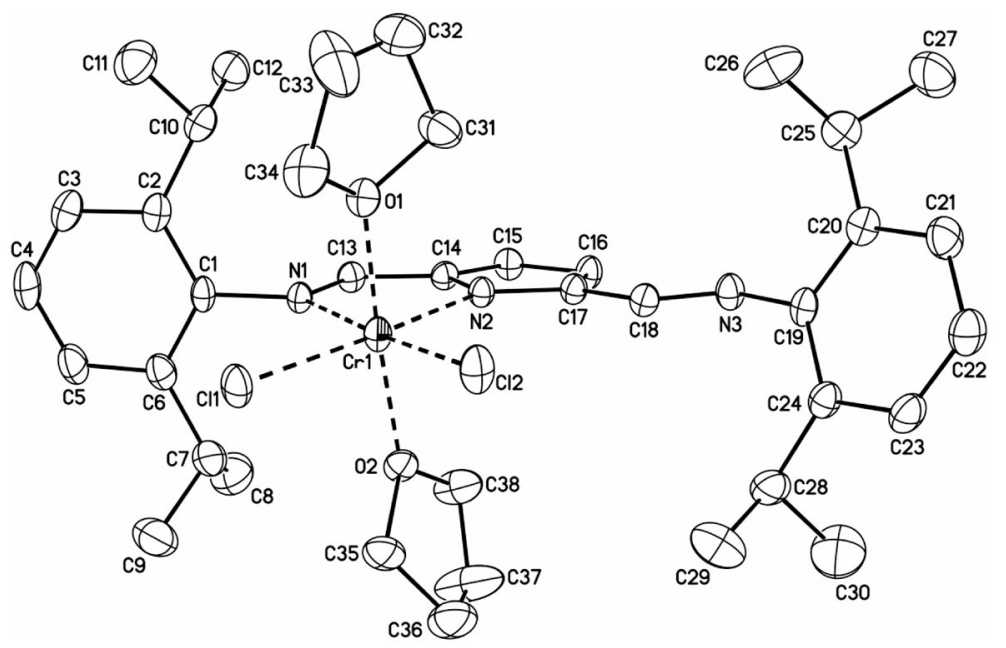

FIG. 1

The molecular structure of $\mathbf{1}$ 
compared to the $\mathrm{Cr}(1)-\mathrm{N}(1)$ distance of $2.116(3) \AA$ clearly reflects the anionic character of the pyrrolide nitrogen. The imine $\mathrm{C}(13)-\mathrm{N}(1)$ bond distance of 1.288(4) $\AA$ remains relatively unchanged from the imine bond distance of the unbound ligand $(1.270(6) \AA)$, indicating no change in the double bond character of the $\mathrm{C}(13)-\mathrm{N}(1)$ imine. There is no conjugation of the bound imine with the pyrrolide ring as indicated by the $C(13)-C(14)$ bond distance of 1.430(4) $\AA$ compared with the average bond distance of the pyrrole ring atoms of $1.387 \AA$. Complex 1 has a room temperature effective magnetic moment of $3.9(1) \mu_{B}$ which is consistent with the three unpaired electrons of a magnetically isolated $\mathrm{Cr}(\mathrm{III})$ ion $\left(\mathrm{d}^{3}\right)$.

The polymerization activity of $\mathbf{1}$ was examined using a variety of activators. The results of the polymerization experiments are shown in Table III. In a typical experiment, $0.010 \mathrm{~g}$ of the pre-catalyst was dissolved in $25 \mathrm{ml}$ of toluene $\left([\mathbf{1}]=5.7 \times 10^{-4} \mathrm{~mol} \mathrm{I}^{-1}\right)$ followed by addition of an activator $\left(\mathrm{MAO}, \mathrm{Et}_{2} \mathrm{AlCl}\right.$, or $\mathrm{EtAlCl}_{2}$ ) via syringe in the dry box. Addition of the activator turned the color of the complex from dark brown to forest green in all cases. The catalyst solution was then placed into a 300-ml Parr reactor and brought out of the dry box. Ethylene was admitted to the reaction vessel and the pressure was adjusted to $1.38 \mathrm{MPa}$. After $1 \mathrm{~h}$ the pressure was released slowly and the reaction was quenched with a 75:25 mixture of methanol/concentrated $\mathrm{HCl}$.

Complex $\mathbf{1}$ showed modest activity with all three activators, with the highest activity associated with the most Lewis acidic activator, i.e., EtAlCl${ }_{2}$. The general trend in activity suggests that the Lewis acidity of the activator plays a role in polymerization activity. Analysis of the polyethylene obtained from experiments 2 and 3 (experiment 1 did not yield enough polymer to warrant analysis) (see Table III) showed broad polydispersities (PDI $=M_{w} / M_{n}$ ) in both cases. The molecular weight distributions were bimodal in both cases, with the main concentration of

TABLE III

Polymerizations with $\mathbf{1}$, all reactions were performed in toluene at $1.38 \mathrm{MPa}$ for $1 \mathrm{~h}$

$\begin{array}{lcccccc}\text { Exp. } & \text { Activator } & \text { Yield } & \mathrm{M}_{\mathrm{n}} / 1000 & \mathrm{M}_{\mathrm{w}} / 1000 & \text { PDI } & \begin{array}{c}\text { Activity } \\ \mathrm{g} \mathrm{mmol}^{-1} \mathrm{bar}^{-1} \mathrm{~h}^{-1}\end{array}\end{array}$

\begin{tabular}{rlrcrcr}
1 & $\mathrm{MAO}(100)$ & 0.080 & \multicolumn{1}{c}{-} & \multicolumn{1}{c}{-} & - & 0.41 \\
2 & $\mathrm{Et}_{2} \mathrm{AlCl}(100)$ & 0.450 & 212.93 & 1308.20 & 6.144 & 2.31 \\
3 & $\mathrm{EtAlCl}_{2}(100)$ & 1.301 & 66.27 & 249.01 & 3.757 & 6.67
\end{tabular}


molecular weights lying at $10^{5}$ and $10^{6}$ for activators $\mathrm{Et}_{2} \mathrm{AICl}$ and $\mathrm{EtAICl}_{2}$, respectively. Thus, there were more than one catalytically active species, in each case, and speculation about the exact nature of these species does not seem warranted.

The interaction of halide complex $\mathbf{1}$ with the various activators presumably results in alkylation of the chromium, followed by abstraction of one of the alkyl groups to produce a cationic coordinatively unsaturated cataIyst. Unfortunately, attempts to prepare and characterize such organometallic derivatives were unsuccessful. Thus, treatment of 1 with either 1 or 2 equivalents of [(trimethylsilyl)methyl]lithium in THF, followed by evaporation and extraction into diethyl ether, yielded light orange-brown solutions. Upon concentration and layering with pentane $\left(\eta^{1}-2,5\right.$-bis $\{$ (2,6-diisopropylphenyl)imino]methyl \}pyrrol-1-ido)( $\eta^{2}-2,5$-bis $\{$ (2,6-diisopropylphenyl)imino]methyl \}pyrrol-1-ido)(tetrahydrofuran)chromium(II) (2) was isolated in $12 \%$ yield as orange crystals. Thus, the synthesis of alkyl derivatives of $\mathbf{1}$ was unsuccessful presumably due to disproportionation of the mono- or dialkyl to a $\mathrm{Cr}(\mathrm{II})$ and $\mathrm{Cr}(\mathrm{IV})$ fragments (Scheme 2).

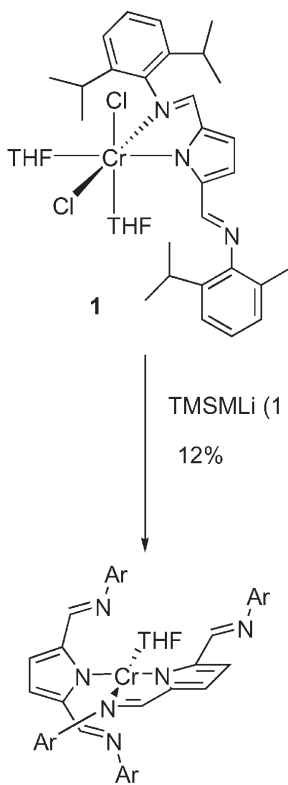

2

SCHEME 2 
Complex 2 can also be synthesized (in better yield) by reacting 2 equivalents of the lithium pyrrolide with chromium(II) chloride. The orange crystals obtained from this reaction exhibited an ${ }^{1} \mathrm{H}$ NMR spectrum identical to that of the product obtained via the disproportionation of the alkylation product.

Crystals of $\mathbf{2}$ were obtained from diethyl ether layered with pentane at $-30{ }^{\circ} \mathrm{C}$ and its molecular structure as determined by X-ray diffraction is shown in Fig. 2; selected interatomic distances and angles are listed in Table IV. Complex $\mathbf{2}$ adopts a pseudo-octahedral geometry, with the both

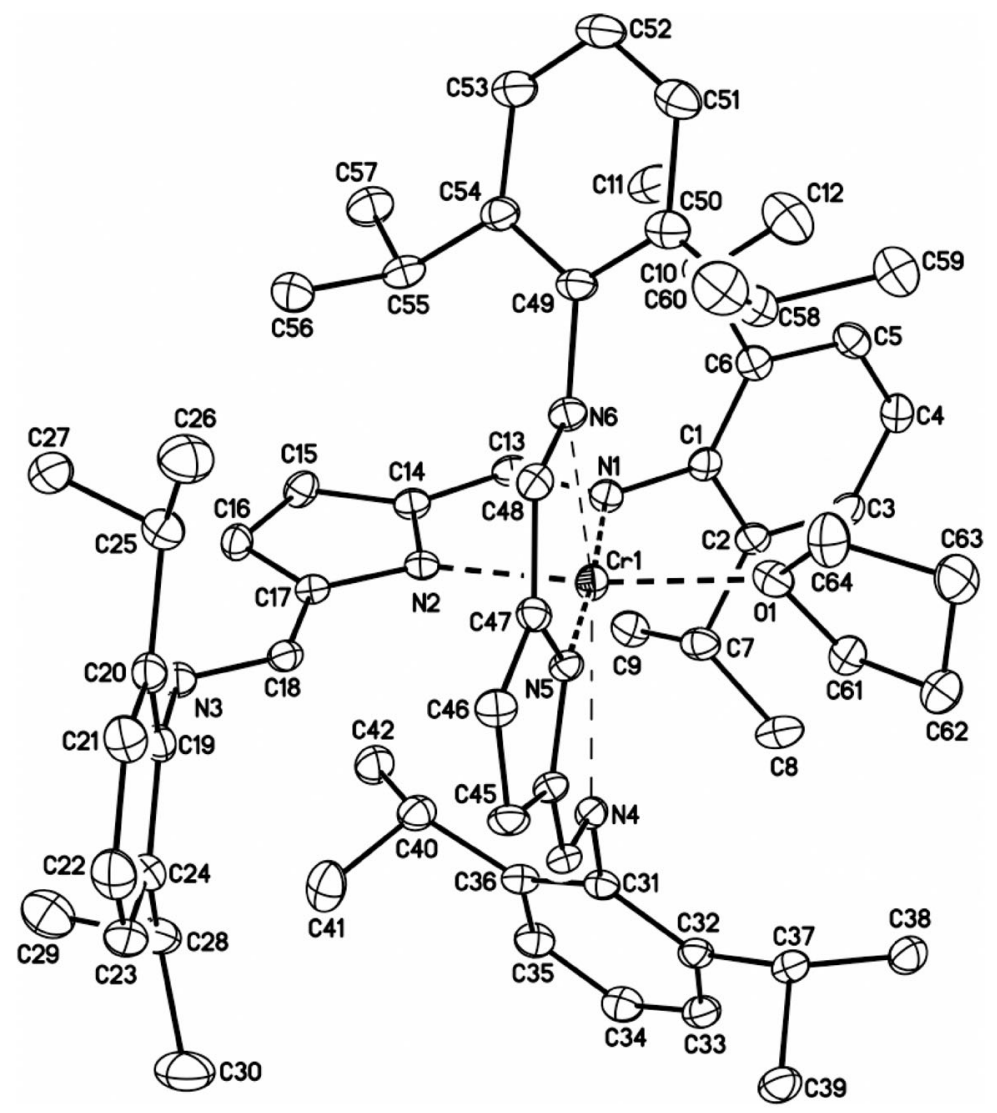

FIG. 2

The molecular structure of $\mathbf{2}$ 
arms of the $\eta^{1}$-pyrrolide ligand interacting equally weakly with the chromium atom. The $\mathrm{Cr}(1)-\mathrm{N}(4)$ and $\mathrm{Cr}(1)-\mathrm{N}(6)$ distances are 2.719(5) and 2.889(5) $\AA$, respectively. This differs significantly from the $\mathrm{Cr}(1)-\mathrm{N}(1)$ distance of 2.107(2) $\AA$, showing the weak bonding nature of the imine arms of the monodentate ligand. Indeed, this particular bonding mode of the pyrrolide-diimine ligand appears to be unprecedented; the structure of $\mathbf{2}$ may be considered a snapshot of a structure on the reaction coordinate of a degenerate ligand substitution reaction of a five-coordinate chromium complex ${ }^{10}$.

The two pyrrolide nitrogens are essentially equidistant from the chromium atom having bond distances of 2.070(2) and 2.033(2) $\AA$ for $\mathrm{Cr}(1)-\mathrm{N}(2)$ and $\mathrm{Cr}(1)-\mathrm{N}(5)$, respectively, indicating their anionic nature. As in complex 1, the second imine group of the bidentate ligand is rotated $180^{\circ}$ away from the metal center. Complex $\mathbf{2}$ has a room temperature magnetic moment of $4.6(1) \mu_{B}$, consistent with 4 unpaired electrons as expected of a high-spin $\mathrm{Cr}(\mathrm{II})\left(\mathrm{d}^{4}\right)$ ion.

We have prepared and characterized a chromium (III) complex of the 2,5-bis \{(2,6-diisopropylphenyl)imino]methyl \}pyrrol-1-ide ligand. The complex showed modest polymerization activity, giving broad molecular weight distributions with all activators used. Attempts to al kylate the $\mathrm{Cr}$ (III) complex resulted only in disproportionation producing the bispyrrolidechromium complex $\mathbf{2}$. Similar results have been reported for the alkylation of $\left[(\mathrm{Ph})_{2}\right.$ nacnac $\left.\} \mathrm{CrCl}_{2}\right]\left((\mathrm{Ph})_{2} \text { nacnac }=2,4 \text {-pentane-di }(\mathrm{N} \text {-phenyl }) \text { ketiminate }\right)^{11}$.

TABLE IV

Selected interatomic distances and angles in complex $\mathbf{2}$

Distance, $\AA$

Angle, $^{\circ}$

\begin{tabular}{lllr}
$\mathrm{Cr}(1)-\mathrm{N}(5)$ & $2.033(2)$ & $\mathrm{N}(5)-\mathrm{Cr}(1)-\mathrm{N}(2)$ & $96.47(9)$ \\
$\mathrm{Cr}(1)-\mathrm{N}(2)$ & $2.070(2)$ & $\mathrm{N}(5)-\mathrm{Cr}(1)-\mathrm{O}(1)$ & $91.38(8)$ \\
$\mathrm{Cr}(1)-\mathrm{O}(1)$ & $2.114(2)$ & $\mathrm{N}(2)-\mathrm{Cr}(1)-\mathrm{O}(1)$ & $171.41(8)$ \\
$\mathrm{Cr}(1)-\mathrm{N}(1)$ & $2.107(2)$ & $\mathrm{N}(5)-\mathrm{Cr}(1)-\mathrm{N}(1)$ & $175.87(9)$ \\
$\mathrm{N}(1)-\mathrm{C}(13)$ & $1.305(3)$ & $\mathrm{N}(2)-\mathrm{Cr}(1)-\mathrm{N}(1)$ & $80.24(9)$ \\
$\mathrm{N}(3)-\mathrm{C}(18)$ & $1.279(3)$ & $\mathrm{O}(1)-\mathrm{Cr}(1)-\mathrm{N}(1)$ & $91.76(8)$ \\
$\mathrm{N}(4)-\mathrm{C}(43)$ & $1.287(3)$ & & \\
$\mathrm{N}(6)-\mathrm{C}(48)$ & $1.289(3)$ & & \\
\hline
\end{tabular}


$\left(\eta^{1}-2,5\right.$-Bis $\{(2,6-d i i s o p r o p y l p h e n y l)$ imino $]$ methyl $\}$ pyrrol-1-ido $)\left(\eta^{2}-2,5\right.$-bis$\{(2,6$-dii sopropylphenyl)imino]methyl \}pyrrol-1-ido)(tetrahydrofuran)chromium(II) (2) was independently synthesized and fully characterized.

This research was supported by a grant from the U.S. National Science Foundation (CHE-0132017).

\section{REFERENCES AND NOTES}

1. a) Britovsek G. J. P, Gibson V. C., Kimberly B. S., Maddox P. J., McTavish S. J., Solan G. A., White J. P., Williams D. J.: Chem. Commun. 1998, 849; b) Small B. L., Brookhart M., Bennett A. M. A.: J. Am. Chem. Soc. 1998, 120, 4049; c) Small B. L., Brookhart M.: J. Am. Chem. Soc. 1998, 120, 7143; d) Britsovek G. J. P., Bruce M., Gibson V. C., Kimberley B. S., Maddux P. J., Mastroianni S., McTavish S. J., Redshaw C., Solan G. A., Stroemberg S., White A. J. P., Williams D. J.: J. Am. Chem. Soc. 1999, 121, 8728; e) Britsovek G. J. P., Mareoinni S., Solan G. A., Baugh S. P. D., Redshaw C., Gibson V. C., White A. J. P., Williams D. J., Elsegood M. R. J.: Chem. Eur. J. 2000, 6, 2221.

2. a) Johnson L. K., Killian C. M., Brookhart M.: J. Am. Chem. Soc. 1995, 117, 6414; b) Killian C. M., Tempel D. J., Johnson L. K., Brookhart M.: J. Am. Chem. Soc. 1996, 118, 11664; c) Pellecchia C., Zambelli A.: Macromol. Rapid Commun. 1996, 17, 333; d) Mecking S., Johnson L. K., Wang L., Brookhart M.: J. Am. Chem. Soc. 1998, 120, 888; e) Johnson L. K., Mecking S., Brookhart M.: J. Am. Chem. Soc. 1996, 118, 267; f) Gates D. P., Svejda S. A., Onate E., Killian C. M., Johnson L. K., Brookhart M.: Macromolecules 2000, 33, 2320.

3. a) Younkin T. R., Conner E. F., Henderson J. I., Friedrich S. K., Grubbs R. H., Bansleben D. A.: Science 2000, 287, 460; b) Matsui S., Mitani M., Saito J., Tohi Y., Makio H., Matsukawa N., Takagi Y., Tsuru K., Nitabaru M., Nakano T., Tanaka H., Kashiwa N., Fujita T.: J. Am. Chem. Soc. 2001, 123, 6847; c) Wang C., Friedrich S., Younkin T. R., Li R. T., Grubbs R. H., Bansleben D. A., Day M. W.: Organometallics 1998, 17, 3149; d) Gibson V. C., Mastroianni S., Newton C., Redshaw C., Solan G. A., White A. J. P., Williams D. J.: J. Chem. Soc., Dalton Trans. 2000, 1069; e) Jones D. J., Gibson V. C., Green S., Maddux P. J.: Chem. Commun. 2002, 1927; f) Tian J., Coates G. W.: Angew. Chem., Int. Ed. 2000, 39, 3626; g) Tian J., Hustad P. D., Coates G. W.: J. Am. Chem. Soc. 2001, 123, 5134; h) Mitani M., Furuyama R., Mohri J., Saito J., Ishii S., Terao H., Kashiwa N., Fujita T.: J. Am. Chem. Soc. 2002, 124, 7888.

4. a) Gibson V. C., Newton C., Redshaw C., Solan G. A., White A. J. P, Williams D. J.: Dalton Trans. 2002, 4017; b) Matsui S., Spaniol T. P., Takagi Y., Yoshida Y., Okuda J.: Dalton Trans. 2002, 4529; c) Yoshida Y., Saito J., Mitani M., Takagi., Matsui S., Ishii S., Nakano T., Kashiwa N., Fujita T.: Chem. Commun. 2002, 1298.

5. a) Dawson D. M., Walker D. A., Thornton-Pett M., Bochmann M.: J. Chem. Soc., Dalton Trans. 2000, 459; b) Matsuo Y., Mashima K., Tani K.: Organometallics 2001, 20, 3510; c) Tsurugi H., Matsuo Y., Yamagata T., Mashima K.: Organometallics 2004, 23, 2797;

d) Matsuo Y., Tsurugi H., Yamagata T., Tani K., Mashima K.: Bull. Chem. Soc. Jpn. 2003, 76, 1965; e) Matsuo Y., Mashima K., Tani K.: Organometallics 2001, 20, 3510. 
6. Dawson D. M., Walker D. A., Thornton-Pett M., Bochmann M.: J. Chem. Soc., Dalton Trans. 2000, 459.

7. Herwig W., Zeiss H. H.: J. Org. Chem. 1958, 23, 1404.

8. Jolly W. L.: The Synthesis and Characterization of Inorganic Compounds. Prentice Hall Inc., New Jersey 1970; and references therein.

9. Integration of this NMR proved to be very difficult due to many overlapping signals in the diamagnetic region.

10. Bürgi H. B., Dunitz J. D.: Acc. Chem. Res. 1983, 16, 153.

11. MacAdams L. A., Kim W.-K., Liable-Sands L. M., Guzei I. A., Rheingold A. L., Theopold K. H.: Organometallics 2002, 21, 952. 